\title{
Optimizing the Potential of Small and Medium Enterprises (Smes) as a Strategy for Exiting the Middle Income Trap: A Case Study in Indonesia
}

\author{
Muhammad Taali ${ }^{1}$, Triana Prihatinta ${ }^{2}$, Ardila Prihadyatama ${ }^{3}$ \\ State Polytechnic of Madiun, Indonesia ${ }^{1,2,3}$
}

\begin{abstract}
This study aims to analyze the potential of small and medium enterprises (SMEs) as a strategy to escape of the middle income trap in Indonesia. Middle income trap is represented by the per capita income, while small and medium enterprises are represented by the number of small and medium business units, the amount of investment, and the number of workers in the small and medium business sector. The variable used as the dependent variable is the per capita income, while the independent variable is the number of small and medium enterprises units, total investment, government expenditure (share \% of GDP), total population, and number of workers in the small and medium business sector. The secondary data used in this study has a time span between 2008 and 2018. The method of analysis used to investigate the impact of independent variables on the dependent variable is the ordinary least square method (OLS). The results found in this study are there is a significant positive effect of the investment variable and government expenditure on the per capita income variable. Meanwhile, the variable number of small and medium enterprises has a significant positive impact on the per capita income variable of the population.
\end{abstract}

Keywords: SMEs, Middle Income Trap, Ordinary Least Square

\section{Introduction}

According to Egawa a middle income trap is a situation where countries that have reached the status of middle income countries experience stagnation in their economic growth, so that they are unable to transition into high income countries due to certain factors [1]. Most Latin American countries can be trapped in middle income countries because they fail to find new strategies for their economic growth when they enter the middle income countries period. The need for economic growth strategies in middle-income countries is very different from those in low-income countries.

Developed countries such as Japan, South Korea, Britain and the United States generally have large levels of real GDP. With relatively smaller populations (except for the United States and Japan) and large real GDP, these countries are able to become countries with high income. In contrast to developing countries, in general, have a larger population (except Cambodia) but relatively smaller real GDP. These conditions make developing countries included in the category of middle income countries. 
The large population is not always a problem to improve the status of a middle-income country. Some high-income countries with large populations such as the United States and Japan is capable of transitioning into a high-income country. This fact shows that these developed countries are able to transition to high-income countries because they have advantages in other factors, such as policies in increasing innovation through $R \& D$, human capital, capital accumulation, and understanding opportunities in new environments [2]. Therefore, the fast economic growth in recent years has helped several developing countries to increase their per capita income. Several developing countries, such as China, India, Brazil, and Indonesia, were even able to catch up with the real GDP behind developed countries. With a large population and positive growth in recent decades,

In general, developed countries have high population productivity. With a certain population level, developed countries have high R\&D expenditures and quality human capital. This condition makes developed countries have high-skill intensive product industrial structures that have high productivity and competitiveness. For example, the difference in real GDP between the United States and developing countries in general is still far behind. With the third largest population in the world, the United States still has the larger real GDP. The real GDP ratio between Japan and developing countries is also still far away (except for China, which succeeded in replacing Japan in 2010 as the second largest economy in the world). Even though the population of Japan is still smaller than India, Indonesia, Brazil and Pakistan.

Most developing countries have the advantage of a relatively large workforce, plus a demographic bonus, and wage levels are still low when compared to developed countries (see table 3). These factors should be used as the main strategy in attracting more FDI and investment in developing countries. However, Agenor et al. stated that in the long run the increase in labor wages will occur in developing countries. If it fails to make changes to the economic structure, these conditions can reduce the competitiveness of commodities allocated to a production activity. This condition can be the main cause of the middle income trap in developing countries. Productivity growth in several sectors will eventually slow down, international competitiveness will decline, output growth will slow down, so that the economy will be trapped and fail to transition into a high-income country.

Problems such as increasing labor wages should be overcome by making changes from production activities that produce products with low value-added to production activities that produce products with higher value-added. Smaller, developed countries tend to be oriented towards capital intensive and skill intensive productivity, as well as focus on the service sector. These factors make developed countries have high competitiveness and productivity, so as to increase the wages of their workers. Therefore, developing countries should improve the quality of human capital and technology in order to be competitive and free from the trap of increasing wages [3].

Correct policies in developing human capital should be an important part of a country's development strategy. Economic theory has demonstrated that economic growth is generated from a synergy between new discoveries and human capital, so that improving the quality of education and training will be accompanied by mastery of technology in the country with which it experiences rapid economic growth. Human capital investment is considered important in driving the economic development of a country [4]. The success of South Korea in increasing the education participation of its population, especially secondary and tertiary education, has made South Korea have an abundant highly skilled workforce [5].

Vandenberg and Zhuang argue that government spending can help developing countries get out of the middle income trap through investments in various fields, especially social 
security such as health and education [6]. However, government spending in some developing countries is still a problem because of the small share of GDP. Based on World Bank data for 2011, government spending in Indonesia and the Philippines is only $9 \%$ and $10 \%$ of total GDP, respectively. This condition is vulnerable because the bureaucratic system in several developing Asian countries is still poor.

The World Bank explains that middle-income countries also need large investments in order to boost their productivity so as to avoid growth slowdowns [4]. South Korea and Japan experienced this condition when they were still middle income countries. Several developing countries such as China, India and Indonesia are already on the right track as they have been able to increase their investment levels in recent years to above $25 \%$ of GDP. However, inadequate infrastructure is a problem currently facing developing countries such as Indonesia, the Philippines and India. Investment in infrastructure is an important factor in maintaining the momentum for increasing economic growth in the long term.

Micro, Small and Medium Enterprises (UMKM) is the most developed industrial sector in Indonesia. BPS data for 2018 recorded that there were 63 million business units operating in Indonesia. When compared with large businesses, the business sector in Indonesia is largely controlled by the MSME sector (almost $99 \%$ of the entire business sector). This is the reason that MSMEs are a potential that needs to be developed as one of the steps to anticipate the middle income trap phenomenon.

Based on this background, this study will analyze the middle income trap with investment variables, government expenditure on GDP, the number of MSME sector workforce, the population and the number of SME's units.

\section{Literature Review}

\subsection{Determinant Variable of Per Capita Income as Efforts to Prevent Middle Income Trap}

According to Todaro, an understanding of the middle income trap can be explained in terms of coordination failure. Where the failure of coordination can result in a growth slowdown [7]. The problem of coordination failure can make an economy trapped in a bad equilibrium, where the growth rate will be low (because investment does not occur) so that it will cause a middle income trap.

Aiyar dkk explains that the middle income trap is a general description of countries that have reached the status of middle-income countries over the years due to slowing growth or growth slowdown. The study analyzed several determinants of growth slowdown where the variables of Institutions, Demography, Macroeconomic Environment and Policies Economic Structure, Wars and Civil Conflicts and Countries area in the Tropics had a significant effect, while the Infrastructure variable had no significant effect.

Middle income trapcan occur when the GDP growth per capita of a country is slowing down. Therefore, macroeconomic factors are very important in explaining this phenomenon middle income trap [8]. State that there are three conditions in explaining the occurrence growth slowdown. First, the average growth of GDP per capita for seven years was only 3.5 percent or more (in the previous period it was able to grow faster). Second, the seven-year average growth has continued to decline by 2 percent (great attention is required). Third, growth slowdown in this case it occurred in a country that had incomes over 10,000 USD at constant 2000 international PPP prices. 
Result pen their research on several determinants of per capita income in several middleincome countries after World War II. The results of this study indicate that several determinants of per capita income, such as the variable Consumption Share of GDP, Investment share of GDP, Government share of GDP, Positive Political Regime, High Technology Export, Inflation, Total Year of Schooling, Year of Schooling at secondary and higher, and Exchange. Rate has a positive effect on GDP per capita. Other variables such as Age Dependency Young and Old, Trade Openness, World GDP growth have a negative effect on GDP per capita.

Egawa also states that several variables such as Education, Health, Working Age Population, and Export share of high tech manufacturing good to total exports have a positive effect and variables such as Income Level, Inequality, Health, and Political decision in line with development have a negative effect [1]. The three previous studies can be used as a reference in describing the influence of variables of per capita income in middle-income countries.

Research from Tho suggests developing countries to increase their R\&D activities, Human Capital, International Competitiveness, Dynamic Comparative Advantage, and build high quality institutions, so they can avoid middle income traps [9]. In addition, Felipe also explained that a country that has successfully transitioned to a high income country is a country that is able to diversify, has advantages, and creates non-standard products for export, so as to develop its comparative advantage [10]. Agenor et al also state that preventing middle income traps can be done by building adequate infrastructure, increasing patent protection, and reforming the labor market.

\subsection{Government Expenditures}

Keynes's theory states that government spending affects economic growth. In the Keynesian model, government spending is autonomous and exogenous, so that government spending can be identified as a policy tool for economic growth and output fluctuations in the long run. The Keynesian model states that a cut in government spending or a reduction in the fiscal deficit will directly result in a decrease in aggregate demand. The impact of a decrease in aggregate demand with a negative multipplier effect is a decrease in economic growth and an increase in the number of unemployed[11]. Thus, the impact of a decrease in government spending can cause a growth slowdown.

\subsection{Investment Expenditures}

One of the main components in Keynes's theory that determines the level of total output besides government expenditures is investment expenditures. Keynes stated that investment expenditure has an effect on the level of total output, where the greater the investment expenditure, the greater the business output produced. In economic development, investment has two important roles in the macro economy. First, its effect on aggregate demand which will drive total output and employment opportunities. Second, as an important component in economic growth. Economic spending has a contribution to economic growth because it can increase capital stock and help the economy produce goods and services [12]. Therefore, the role of investment is vital in increasing the productivity of a country. 


\subsection{Population Factor}

One of the important issues in the development problems of a country is the issue of demography. Thomas Robert Malthus (1766-1834) who explained that population growth can hinder economic development if it is not properly controlled. In the Solow model it is also explained that countries with high population growth will have low per capita income. Countries with high population growth will have a low steady-state capital stock per worker as well as low levels of income per worker. Population control is very important in improving the welfare of the population in poor countries [13].

The human capital factor is an important factor in an economy because it involves the ability of human resources in more efficient productivity activities. This is in accordance with the concept of economic growth in Solow which emphasizes the role of science and human capital investment in spurring labor productivity. The higher the quality of human resources, the more efficiency and productivity will increase.

The Campbell and Stanley curve depicts the relationship between education level and income earned [14]. Region 1 (Direct Cost) is the cost sacrificed due to delaying work, so it has a negative value. Region 2 (Indirect Cost) is the opportunity cost of workers with further education compared to secondary education. Region 3 (Incremental Earnings) is the income earned by someone with further education rather than secondary education. Thus, it can be concluded that someone with higher education has a higher income than those who do not continue their education.

The dependency ratio is the ratio of the population of non-productive age (aged less than 15 years and more than 64 years) to the population of productive age (15-64 years). A large degree of dependence can hinder economic development because the productive age population has to bear a greater burden on the non-productive age population. Middle income trap can be caused by population factors, especially at high fertility rates and high population dependency ratios. These problems are often found in developing countries. Changes in the demographic structure are known to affect economic development and technically can affect economic growth [1]. According to John Stuart Mill, poverty (due to the high level of population dependency) can be overcome by changing the demographic behavior of the population through education. Someone who has a higher education tends to have a smaller family because they will consider their existing career and business [15].

\subsection{Framework}

The relationship between variables such as investment, government spending, total workforce, population, and the number of MSMEs to the Gross Domestic Product variable can illustrate the phenomenon of the existence of Middle Income Trap in Indonesia. The framework that explains the flow of this research will be described through the following schema. 


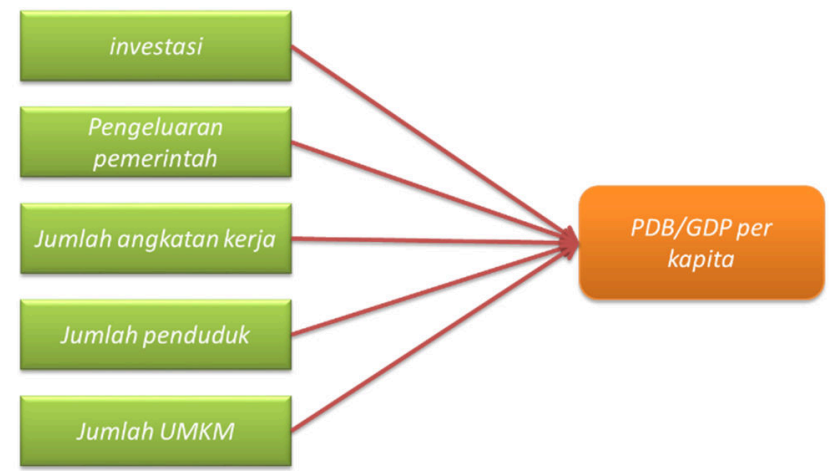

Fig. 1. Framework

Source: Author's Illustration, 2020.

Based on the framework described previously, the hypotheses formulated in this study are as follows:

a. The investment variable has an effect on the Gross Domestic Product in Indonesia.

b. Government expenditure variables have an effect on the Gross Domestic Product in Indonesia.

c. Variable number of labor force affects the Gross Domestic Product in Indonesia.

d. Population variable has an effect on the Gross Domestic Product in Indonesia.

e. The variable number of umkm has an effect on the Gross Domestic Product in Indonesia.

\section{Research Methods}

The type of approach used in this research is a quantitative approach. This research is a replication of previous studies. However, in this study there were differences in the time of observation, variable parameters, and the methods used. The data used in this study is time series data sourced from worldbank.org, the Indonesian Central Bureau of Statistics. The planned research timeframe is from 2008 to 2018 . The operational definition of each variable will be explained in the following table:

Table 1. Operational Definitions of the Variables

\begin{tabular}{llll}
\hline Notation & Variable Name & Description & Reference source \\
\hline $\begin{array}{l}\text { GDP Per Cap / } \\
\text { GDP per capita }\end{array}$ & $\begin{array}{l}\text { Income per capita } \\
\text { every year }\end{array}$ & Dollar & data.worldbank.org \\
Investation & $\begin{array}{l}\text { Investments made in } \\
\text { Indonesia }\end{array}$ & Dollar & data.worldbank.org \\
$\begin{array}{l}\text { Government } \\
\text { spending to GDP }\end{array}$ & $\begin{array}{l}\text { Ratio of government } \\
\text { spending to GDP } \\
\text { Workforce }\end{array}$ & Percent & data.worldbank.org \\
& $\begin{array}{l}\text { Number of population } \\
\text { who are in productive } \\
\text { age (14-60 years) }\end{array}$ & Person & bps.go.id \\
GDP Per Cap / & $\begin{array}{l}\text { Income per capita } \\
\text { every year }\end{array}$ & Dollar & data.worldbank.org \\
GDP per capita & \multicolumn{3}{c}{ Source: author's calculations, 2020. }
\end{tabular}

While the analysis tool used is the Engle Granger Error Correction Model (ECM-EG) or often referred to as the Engle Granger Error Correction Model. As explained in Insukindro 
(1999), ECM is often seen as one of the most well-known dynamic models and is widely applied in empirical studies, especially since the failure of the Partial Adjustment Model (PAM) in the 1970s in explaining the dynamic behavior of money demand [16].

ECM itself is used to explain why economic actors face a disequilibrium in the context that the phenomena desired by economic actors are not necessarily the same as what is actually (actual) and the need to make adjustments as a result of differences in actual phenomena (actual) faced over time. The steps that must be taken before forming an ECM model are as follows:

\section{a) Unit root test}

The purpose of this data stationary test is to observe whether the data is stationary or not. A data can be said to be stationary if there are no unit roots. In time series analysis, information about the stationarity of a data series is very important because including nonstationary variables in the regression coefficient estimation equation will cause the resulting standard error to be biased. The existence of this bias will invalidate conventional criteria which are used to justify causality between two variables. This means that estimation using a variable that has a unit root (non-stationary data) can result in incorrect forecasting because the estimator coefficient is inefficient. In this research,ADF Test (Augmented Dickey Fuller Test), Phillips Perron Test (PP Test) and KPSS Test (Kwiatkowski - Phillips - Schmidt - Shin Tests) [17].

\section{b) Cointegration Test}

According to Engle and Granger, a linear combination between two or more non-stationary data series will result in stationary integration. Stationary linear combination can also be said to be a cointegrating equation, and can be interpreted as a long-term equilibrium relationship between the existing variables. Thus, the aim of the cointegration test is very clear, namely to determine whether groups of non-stationary data series are cointegrated or not. In this study, the cointegration test used was the two-step Engle Granger method (two-step Engle Granger). The test stages are described in the following sequence:

1. Test the stationarity of the $\mathrm{Yt}$ and $\mathrm{Xt}$ variables by using one of the unit root testing methods (eg ADF test). The two variables must be stationary at the degree of difference to ensure the presumption of cointegration between variables.

2. Estimation of the variable $\mathrm{Xt}$ as a function of $\mathrm{Yt}$, resulting in a residual value of $\varepsilon \mathrm{t}$.

3. Do a stationarity test of the et variable, if it is stationary, it can be concluded that there is cointegration between the $\mathrm{Yt}$ and $\mathrm{Xt}$ variables.

After the cointegration between variables can be confirmed, the next step is to compile an ECM model with the following functions:

$$
\begin{aligned}
\text { GDPpercapt }= & \alpha+\beta 1 \text { invt }+\beta 2 \text { gov_expt }+\beta 3 \text { kerjat_pendudukt }+ \\
& \beta 4 \text { jml_pendudukt }+\beta 5 \_ \text {_ukmt_ukmt }+ \text { ECT }+\varepsilon t .
\end{aligned}
$$

Information :

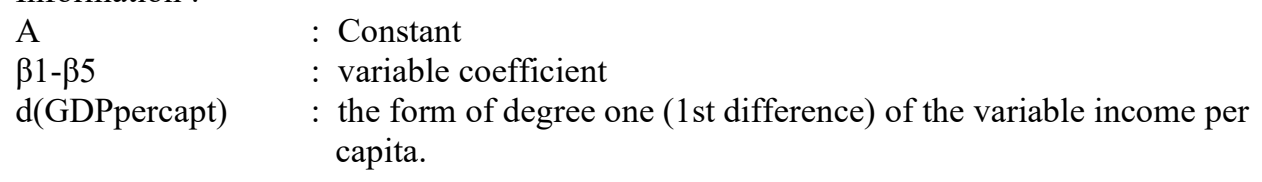




\begin{tabular}{|c|c|}
\hline $\begin{array}{l}\text { d(inv) } \\
\text { d(gov_exp) }\end{array}$ & $\begin{array}{l}\text { : the form of degree one ( } 1 \text { st difference) of the investment variable. } \\
\text { : the form of degree one ( } 1 \text { st difference) of the government } \\
\text { expenditure ratio variable. }\end{array}$ \\
\hline & $n$ of degree one (1st difference) of the labor force variable. \\
\hline tion_count) & $\begin{array}{l}\text { the form of degree one ( } 1 \mathrm{st} \text { difference) of the population variable. } \\
\text { the form of degree one ( } 1 \mathrm{st} \text { difference) of the population variable. }\end{array}$ \\
\hline & ror Correction Term \\
\hline & Residual \\
\hline
\end{tabular}

\section{Result and Discussion}

\subsection{Descriptive Statistics}

The development of variables cannot be separated from the moving average, variance and standard deviation of the data. The following will present the results of descriptive analysis of some of the variables considered in this study. This descriptive statistical calculation is based on annual data for each variable sourced from the official worldbank.org website. The time span of the data used is from 2008 to 2018.

Table 2. Descriptive Statistics

\begin{tabular}{|c|c|c|c|}
\hline Variable & Average & Variant & $\begin{array}{l}\text { Standard } \\
\text { Deviation }\end{array}$ \\
\hline GDP_percapt & 3397.08348 & 373299.9805 & 610.9827989 \\
\hline Investation & 1.962892774 & 0.439073066 & 0.662625887 \\
\hline Gov_exp & 9.202277569 & 0.147111828 & 0.383551597 \\
\hline workforce & 122582659.8 & $5.53871 \mathrm{E}+13$ & 7442251,796 \\
\hline $\begin{array}{l}\text { Total } \\
\text { population }\end{array}$ & 253275078 & $1.35463 \mathrm{E}+14$ & 11638861.8 \\
\hline $\begin{array}{l}\text { Number of } \\
\text { MSMEs }\end{array}$ & 107843.4346 & 124335176.1 & 11150.56842 \\
\hline
\end{tabular}

\subsection{Framework Unit Root Test (ADF Test, PP Test and KPSS Test)}

Before analyzing the ECM model, the first step in analyzing time series data is to test the data stationarity. In this unit root test, the type of test is carried out, namely the unit root test without structural break. Unit root testing without a structural break is done through the ADF Test (Augmented Dickey Fuller Test), the Phillips Perron Test (PP Test) and the KPSS Test (Kwiatkowski - Phillips - Schmidt - Shin Tests). The consideration for these three tests is to get consistent results Cavoli. The unit root test in this study will be carried out at two different degrees, namely the degree of level and the degree of difference. A summary of the unit root test results for the four variables is presented in the following table:

\begin{tabular}{lccc}
\multicolumn{4}{c}{ Table 3. Unit Root Testing (ADF, PP and KPSS) at the Degree Level } \\
\hline \multicolumn{1}{c}{ Variable } & ADF & PP & KPSS \\
\hline GDP & & & \\
Trend & 0.302021 & 0.130395 & $0.609419^{* *}$ \\
trend and & -1.895353 & -1.625285 & $0.143530^{*}$ \\
intercept & & & \\
\hline
\end{tabular}




\begin{tabular}{lccc}
\hline \multicolumn{1}{c}{ Variable } & ADF & PP & KPSS \\
\hline $\begin{array}{l}\text { None } \\
\text { Investation }\end{array}$ & 2.234871 & 1,798647 & - \\
$\begin{array}{l}\text { Trend } \\
\text { trend and }\end{array}$ & 0.942106 & 1.170205 & $0.655264^{* *}$ \\
intercept & -2.498421 & -2.186048 & $0.172364 * *$ \\
$\begin{array}{l}\text { None } \\
\text { Gov_exp }\end{array}$ & 3.884837 & 4.408216 & - \\
$\begin{array}{l}\text { Trend } \\
\text { trend and }\end{array}$ & $-2.759124 *$ & $-2.802827 *$ & $0.359754^{*}$ \\
intercept & $-3.501994^{*}$ & $-3.514292 *$ & $0.152632^{* *}$ \\
None & & & \\
$\begin{array}{l}\text { Workforce } \\
\text { Trend } \\
\text { trend and }\end{array}$ & -0.594130 & -0.656264 & - \\
intercept & 1.784468 & -0.554995 & 0.584193 \\
None & 3.305616 & -2.587699 & 0.178373 \\
& 1.389662 & 0.424244 & - \\
\hline & Source: author's calculations, 2020.
\end{tabular}

The unit root test for the four variables at the degree level shows that only the gov_exp variable is stationary in the three test methods. Meanwhile, other variables, namely GDP, investment, and labor force show inconsistent results. The summary of the results above can be concluded that, the stationarity test should be continued at the 1 st degree of difference. Regarding the test results, it can be seen in the following table.

Table 4. Unit Root Testing (ADF, PP and KPSS) at the 1st difference

\begin{tabular}{llll}
\hline Variable & ADF & PP & KPSS \\
\hline GDP & & & \\
Trend & $-3.674413 * *$ & $-3.651587 * *$ & 0.187913 \\
trend and intercept & $-3.687686 * *$ & $-3.661496 * *$ & 0.094295 \\
None & $-3.197428 * * *$ & $-3.199011 * * *$ & - \\
Investation & & & \\
Trend & $-3.431687 * *$ & $-3.468740 * *$ & 0.283804 \\
trend and intercept & $-3.492785 *$ & $-3.487765 *$ & $0.174808 * *$ \\
None & $-2.639213 * *$ & $-2.639213 * *$ & - \\
Gov_exp & & & \\
Trend & $-8.043339 * * *$ & $-10.20007 * * *$ & 0.080218 \\
trend and intercept & $-7.973540 * * *$ & $-12.47536 * *$ & 0.063104 \\
None & $-8.178298 * * *$ & $-10.14566 * * *$ & - \\
Workforce & & & \\
Trend & 3.321887 & $-8.076124 * * *$ & $0.295531 * *$ \\
trend and intercept & 1,942177 & $-9.675297 * * *$ & $0.500000 * * *$ \\
None & 4.084798 & $-7.381287 * * *$ & - \\
\hline & Source: author's calculations, 2020. & \\
& &
\end{tabular}

From the above test, all the variables studied were stationary at the 1 st difference level in both the KPSS, PP and ADF tests. These results can be concluded from all the values of the ADF Test and PP Test greater than the critical value at alpha 10\%. Meanwhile, for the KPSS test, the value of the KPSS test is smaller than the critical value at $10 \%$ alpha (so that it will accept the Null hypothesis which states the variable is stationary). The same degree of integration (ie at the 1st difference) indicates that the variables are co-integrated. This was 
revealed by Rumahorbo, where the variables that are stationary at the same degree are thought to have a cointegration relationship [18].

The unit root test in this study used the general to specific method. The general to specific method is a method that starts a unit root test by entering trends and interceptions, then equations with intercept only and finally equations without interceptions and trends into the model.

\subsection{Cointegration Testing and Model Estimation}

Cointegration testing is closely related to testing the possibility of a long-run equilibrium relationship between economic variables as required by economic theory. The cointegration approach can also be viewed as a theory test and is an important part of the formulation and estimation of a dynamic model Engle and Granger [17].

The results displayed in the stationarity test indicate the possibility of a long-term relationship between variables. The results of long-term cointegration testing for each variable can be presented in the following table.

Table 5. Model Estimation

\begin{tabular}{|c|c|c|c|}
\hline Variable & coefficient & Std Error & t-stat \\
\hline $\mathrm{C}$ & $-84.82951 *$ & 41.8516 & -2.03 \\
\hline Investation & $0.0830449 *$ & 0.0323886 & 2.56 \\
\hline Gov_exp & $0.0887939 *$ & 0.0445854 & 1.99 \\
\hline workforce & -2.030705 & 7.029884 & -0.29 \\
\hline $\begin{array}{l}\text { Total } \\
\text { population }\end{array}$ & 12,5162 & 11.4496 & 1.09 \\
\hline $\begin{array}{l}\text { Number of } \\
\text { MSMEs }\end{array}$ & $-1.28 \mathrm{E}-05 *$ & $6.05 \mathrm{E}-06$ & -2.11 \\
\hline $\mathrm{R} 2$ & 0.8814 & & \\
\hline Adj R2 & 0.7826 & & \\
\hline Prob F & 0.0095 & & \\
\hline $\mathrm{N}$ & 12 & & \\
\hline
\end{tabular}

* significant at alpha 0.10

** significant at alpha 0.05

** significant at alpha 0.01

The results of the long-term model estimation above indicate that the investment variable has a significant influence on the GDP variable with the coefficient 0.0830449(at $\alpha=10 \%$ ). Then, the variable Gov_exp also has a significant effect on GDP with the coefficient0.0887939(at $\alpha=\overline{10} \%$ ). However, an interesting fact is the finding of a significant negative relationship between the variable number of MSMEs and GDP with a coefficient of$1.28 \mathrm{E}-05$ at an error tolerance level of $10 \%$. These findings indicate a negative relationship between the increase in the number of MSMEs and the GDP variable. The increase in the number of small and medium enterprises causes a decline in GDP.

Table 6. Cointegration Test (Engle Granger Cointegration Test) Long Run Model Residues

\begin{tabular}{llll}
\hline Variable & ADF & PP & KPSS \\
\hline Residual (level) & & & \\
Trend & -2.484103 & -2.482201 & 0.081362 \\
trend and intercept & -2.433620 & -2.431615 & 0.076000 \\
\hline
\end{tabular}




\begin{tabular}{llll}
\hline Variable & ADF & PP & KPSS \\
\hline None & $-2.531375 * *$ & $-2.530140 * *$ & - \\
Residual (1st difference) & & & \\
Trend & $-4.557661 * * *$ & $-4.560226 * * *$ & 0.133303 \\
trend and intercept & $-4.465847 * * *$ & $-4.468914 * * *$ & $0.133091 *$ \\
none & $-4.646581 * * *$ & $-4.648747 * * *$ & - \\
\hline
\end{tabular}

Source: author's calculations, 2020.

The stationarity test for the residual variables shows that the residuals of the long-run model are stationary at the degree level. This indicates that a long-term relationship between each variable is considered as the research sample. The long-term relationship is due to the data movement which is not only influenced by trend movements, but it is possible that there is a long-term influence that does show the relationship between variables in the future.

If a long-term variable relationship occurs, the next stage of analysis is to compile an ECM model to detect an imbalance between the long-term and the short-term models. For a more complete analysis of the ECM model, please see the following subsections.

\subsection{Error Correction Model-Engle Granger (ECM-EG)Cointegration Testing and Model \\ Estimation}

Based on the estimation results of the short-term model presented in table 4, it can be seen that the four independent variables do not have a significant impact on the GDP variable The residual variable coefficient value shows a positive and insignificant result, this indicates that the ECM model is not valid.

Table 7. Long Run Estimation Model

\begin{tabular}{llll}
\hline Variable & Coefficient & Std Error & t-stat \\
\hline Investasi & 0.0526687 & 0.041655 & 1.26 \\
Gov_exp & 0.0377419 & 0.0684387 & 0.55 \\
Angkatan & -1.156181 & 7.047846 & -0.16 \\
kerja & & & \\
Jumlah & 11.60921 & 47.27625 & 0.25 \\
penduduk & & & \\
Jumlah & $-7.33 \mathrm{E}-06$ & $5.37 \mathrm{E}-06$ & -1.36 \\
UMKM & & & \\
Res & 0.6682371 & 0.5967947 & 1.12 \\
cons & -0.0134038 & 0.2882413 & -0.05 \\
R2 & 0.6517 & & \\
Adj R2 & 0.1292 & & \\
F-statistic & 0.434 & & \\
N & 11 & & \\
\hline
\end{tabular}

Source: author's calculations, 2020.

* significant at alpha 0.10

** significant at alpha 0.05

** significant at alpha 0.01 


\section{Conlusion}

Middle Income Trap is a common phenomenon in developing countries. This study tries to examine the relationship between MIT and the development of MSMEs in Indonesia. The finding of this study is that there is a significant negative effect of the variable number of MSMEs on GDP per capita in Indonesia. In addition, the effect of investment and government spending has a significant positive impact on GDP per capita in Indonesia. The research model was developed into a dynamic model, namely the Engle Granger error correction model (ECM-EG), but in this model there was no significant effect of the five independent variables used.

The UMKM sector is a sector that controls the processing sector in Indonesia. This is the reason that MSMEs are able to become a solution for Indonesia to leave MIT. However, findings that contradict this theory indicate that there are weaknesses in the MSME sector that need to be improved. Among them are related to production efficiency and the problem of low added value in MSMEs.

\section{Acknowledgements}

The author would like to thank those who have provided suggestions and criticism for the improvement of this paper.

\section{References}

[1] A. Egawa, 'Will Income Inequality Cause a Middle-income Trap in Asia?', Bruegel, vol. Vol. 797, 2013.

[2] S. Jitsuchon, 'Thailand in a Middle-income Trap', TDRI Q. Rev., vol. 27(2), pp. 13-20., 2012.

[3] M. Carnovale, Developing Countries and the Middle-Income Trap: Predetermined to Fall. New York.: New York University, Leonard N. Stern School of Business, Bachelor of Science, 2012.

[4] J. Y. Lin, New structural economics: A framework for rethinking development and policy. The World Bank., 2012.

[5] A. N. and J. P. Jankowska, A., The Product Space and the Middle-Income Trap: Comparing Asian and Latin American Experiences. OECD Development Centre Working Papers, No. 311: OECD Publishing, Paris., 2012.

[6] J. Vandenberg, P., \& Zhuang, 'How can China avoid the middle-income trap.', Asian Development Bank., 2011.

[7] S. C. Todaro, M. P., \& Smith, Economic development, Tenth edit. 2009.

[8] B. Eichengreen, 'ADB Distinguished Lecture Renminbi', ADB Disting. Lect. Renminbi Int. Tempest a Teapot?. Asian Dev. Rev., vol. Vol. 30 (1, pp. 148-164., 2013.

[9] K. Thorn, Blended Learning. How to Integrate Online and Tradicional Learning. London : Kogen Page., 2003.

[10] U. Felipe, J., Abdon, A., \& Kumar, Tracking the middle-income trap: What is it, who is in it, and why? Levy Economics Institute, Working Paper, (715)., 2012.

[11] H. Sudarsono, 'The Relationship between Economic Growth and Government Spending: A Case Study of OIC Countries', J. Ekon. Pembang. Kaji. Masal. Ekon. dan Pembang., vol. 11(2), pp. 149-159., 2015. 
[12] H. Kuncoro, 'The Impact of Intergovernmental Transfer on Fiscal Performance, Economic Growth, and Regional Disparity in Indonesia', Unpublished Dissertation, Universitas Gadjah Mada, Yogyakarta., 2005.

[13] and W. M. S. Mankiw, N. G., Macroeconomic, 3rd ed. New York: Worth Publishers, 2007.

[14] S. Campbell, R. Mc.Connel and L. B., Contemporary Labor Economics. New York, USA: McGraw-Hill Book Company, 1986.

[15] H. Kharas, H., \& Kohli, 'What is the middle income trap, why do countries fall into it, and how can it be avoided?', Glob. J. Emerg. Mark. Econ., vol. 3(3), pp. 281-289., 2011.

[16] M. Srholec, High-tech exports from developing countries: A symptom of technology spurts or statistical illusion? 2005.

[17] M. Xiaohe, 'How China Can Avoid the" Middle-Income Trap"', China Econ., vol. 7(1), p. 98., 2012.

[18] V. T. Tran, 'The Middle-Income Trap: Issues for Members of the Association of Southeast Asian Nations.', SSRN Electron., 2013. 